\title{
Developing competency-based assessment at Vocational High School (VHS) in Bali
}

\author{
Dessy Seri Wahyuni * \\ Department of Informatics and Engineering Education, Universitas Pendidikan Ganesha. \\ J1. Udayana No.11, Banyuasri, Buleleng, Bali 81116, Indonesia. \\ * Corresponding Author. Email: seri.wahyuni@undiksha.ac.id
}

\section{ARTICLE INFO}

\section{Article History}

Received:

6 January 2021;

Revised:

22 January 2021;

Accepted:

8 February 2021;

Available online:

18 August 2021

\section{Keywords}

Competency-based assessment (CBA);

Vocational High

School (VHS);

Competency standards;

Qualitative Exploratory

Descriptive (QED)

\begin{abstract}
This paper aims to resolve the difficulties of implementing competency-based assessment (CBA) in vocational high school while practicing in the workplace. This research was performed employing a qualitative exploratory descriptive (QED) method. The respondents are 109 participants from vocational teachers, industry experts, VHS students, and technical certification organizations. The implementation of CBA generates the competency standards of graduates in schools that meet the industry's competency needs. CBA is carried out by creating competency levels, college and workplace learning as students practice doing industrial work. This study's findings suggest aspects of CBA that provide a fair degree of application of the student's business work activities and presents an approach to explaining training that is not limited to learning contexts.
\end{abstract}

This is an open access article under the $\underline{\mathrm{CC}-\mathrm{BY}-\mathrm{SA}}$ license.

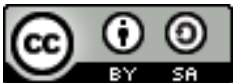

How to cite:

Wahyuni, D. S. (2021). Developing competency-based assessment at Vocational High School (VHS) in

Bali. Jurnal Pendidikan Vokasi, 11(1), 59-67. https://doi.org/10.21831/jpv.v11i1.37383

\section{INTRODUCTION}

A country's life may be portrayed by the development of its economy and the prosperity of people that are highly influenced based on the standard of vocational learning to promote the employability of competent workers in the workplace (Grosch, 2017). Skilled school is part of a structured education structure directly associated with the training or further training for nonbachelor-graduate professions (Bamalli, 2014). As the industry is highly dynamic and technologically advanced, businesses require trained and expert graduates to contribute technically to the market, that company businesses are performed. Therefore, it becomes more difficult for Vocational High School (VHS) to set up vocational students' trainees from their working capabilities. Under Law of the Republic of Indonesia number 20 of 2003, one of the fundamental goals of VHS is to train learners that can collaborate with the competence of each student productively (Presiden Republik Indonesia, 2003). Students have been taught a skill that is used according to the requirements of their job. Implementing a double education system through the idea of "the link match" as an achievement for the preliminary steps of the government is to engage the industry in vocational training. Three key characteristics of activity that deserve to be addressed in its delivery 
are: 1.) A psychomotor field focus; 2.) A technical advancement focus; and 3.) An occupational orientation. The VHS addresses in Indonesia the requirements and qualifications of ever more complex skills in the workforce that needs performance and work skills based on the industry's requirements.

Problems in skilled labor practice execution are: 1.) The beliefs in the world of work (DUDI) in the skills of learners are still fragile; 2.) The role of highly skilled labor experience is contrary with the expertise program; and 3.) The use of the DUDI in industrial labor exercise has been well embraced. These are all the problems that keep the industry or the government entities uncertain about skilled students' performance. Students can also learn new expertise in industrial work training; their job experience will be valuable. The school and industry should ultimately facilitate this operation. Industrial work practice is a technical higher education program where students are explicitly put in the field of jobs to get the expertise and are adequately prepared for work.

The conceptual change in education and learning starts with a performance review (Alonzo, 2018). The idea implies a greater understanding of the learner by integrating instruction, expertise, and judgment. This means that an inalienable partnership among teaching, learning, and evaluation will enhance the awareness of students and teachers to teach them well. The Competency-Based Assessment (CBA) applies to the laws of work and the achievement of levels of work competence (Fletcher, 2000). As an approach to developing work-related ability requirements, CBA showed its focus on skills in the necessary skills of the job (Hasan \& Pardjono, 2019). There is a comparison in the competence-based assessment that employs the quality of working skill competence based on industry needs.

The skilled training competence test consists of two core essentials, specifically the gathering and use of the factual of the students' skill to determine whether a student has achieved the national level of competence specified or contained in the curriculum applied (Albanese et al., 2010). The technical skills of students with experience play a role in the willingness them joining the labor force. It is about their experience, which supports the main industrial work of the world. The conduct of an integrated test of competency must also be accompanied by integrated teaching and teaching practices and combined with the creation of curriculum content. So, within teaching, learning, and skills testing, this activity is an interlinked process that can be configured. This requires that curriculum development and learning systems must be aligned.

The CBA is currently run on a non-employment evaluation scheme at VHS in Indonesia. Learners who have performed their applied training in a school workshop and industry are evaluated in partnership with manufacturing or institute to certification competencies. The CBA approach is less productive since they receive the skills test separately based on their skill cluster. Work-based evaluation is an integrative CBA since students are tested and do any actual work in the factory while doing manufacturing work.

This research aims to establish a Competency-Based Assessment (CBA) approach that collaborates with creating skills, curriculum content, skills-based learning, and manufacturing training in relation. This research's main objective is to form a functional evaluation approach of students in VHS and manufacturing work practice aspects in VHS. The competency-based appraisal currently conducted by VHS students takes high cost and time, as it is operated independently in each competency. The Competency-Based TVET (Technical Vocational Training) approach is based on "occupational competencies" set for occupation area and career path. A Competency-based TVET system typically requires combinations of powerful technology to provide for the requirements of diverse industries (demand), curriculum or skills-based training programs to be established, competency-based assessments or verifications to be performed, staff/apprentices/trainee(s) to be adequately and competently educated..

\section{RESEARCH METHOD}

This research was performed employing a qualitative exploratory descriptive (QED) method as a naturalistic inquiry. The QED research technique allows researchers to consider the real-world meaning that respondents experience: what works and what does not work (Patton, 2014). The method helps the researcher describe the issue of concern and detect meaningful features related to 
actual events (Sandelowski, 2000). Particularly when the issue is not understood, or the problem is too difficult for other approaches to be established (e.g., the survey on the questionnaires), QED analysis is suited (Patton, 2014). It is regarded as a convenient method to answer basic and practical questions such as those posed in this study (Patton, 2014). The study was conducted in three Vocational High Schools (VHS) levels and industries in Bali, Vocational Education Development Center (VEDC) in Malang, and Bandung as a technical certification organization. The respondents were participated by fifty vocational teachers, seven industry experts, fifty students of VHS, and two technical certification organizations and interviewed.

The literature study is achieved by analyzing the aspects examined, whether from the study's theory, the findings of the research, or field studies relating to the competence test. Development of the draft competency-based assessment undertaken through literature review and expert opinion across FGD with academicians, industry experts, instructors, government institutions in this context invited educational and cultural department. Data was collected through in-depth interviews $(n=109)$, which via direct touch, posted flyers on letters of invitation to participant organizations, participants in comprehensive interviews were invited. Individually, they were interviewed using large, semistructured questions to generate awareness, perceptions, and VHS experiences, internship process, and skills assessment. The period ranged from 30 to 120 minutes in individual interviews.

The study tries to create a skill-based assessment model at VHS designed to produce outcomes in configuring a VHS work-based evaluation approach. The aspects of the procedure established including (a) competence criteria identification, (b) teaching, learning, and practicing development, (c) industrial work practice development, (d) skills testing effect (e) curriculum development. The contents of each aspect are: 1.) Competence criteria development, national Indonesian competency standards, and the industrial needs become a guide in formulating core competence/Indonesia qualification standard competence; 2.) Teaching, learning, and practicing development in VHS, Teachers must be accredited with technical skills according to the subject area relevance with their expertise and teachers as independent information systems mentors, competency-based learning model, module learning for students, soft skills in the form of the VHS are offered to students; 3.) Industrial work practice development, students, prefer competence groups with industry support, students practice their skills by competence groups, and evaluations are carried out using competence tests. In contrast, students work as network technicians on their desired competence cluster, with competent or incompetent results; 4.) Skills testing development, competency-based testing takes place on real work, professor as assessor, certificate qualifications become proof of student competence ownership of VHS, CBA has a center, and VHS has certification institutions of its own (such as Professional Certification Institute/LSP, Vocational Education Development Center (VEDC)), LSP works jointly as an independent institution within the national certification body, (such as National Agency for Professional Certification/BNSP); and 5.) Curriculum content creation, VHS, and partner institutions build content by aligning curriculum with established skills in SKKNI and educational ministry program scope. The curriculum at the education unit level is a combination of graduate levels and the national academic curriculum of the educational department with SKKNI.

\section{RESULT AND DISCUSSION}

The outcomes of intensive interviews with students, educators, and expertise industries were interpreted and directed by discussion. The topic covers aspects of competence criteria development; teaching, learning, and practicing development in VHS; Industrial work practice development, Skills testing development in Bali.

\section{Competence Criteria Development}

The skills level in vocational training is based on an SKKNI (Indonesian National Work Competency Standards) combination in the engineering subfield's field with the competence criteria of Ministry of Education and Culture of the Republic of Indonesia graduates covering aspects of expertise, attitude, and ability. In preparation for function, SKKNI serves as a basic standard for 
developing working skills competence based on education level, divided into cognitive, psychomotor, and affective area achievement. The traditional role analysis starts with analyzing technical skills job and finishes with creating a description of competence (Craddock et al., 2013). It indicates that the job requires research defined in SKKNI and built to a level of competence that must be done in competency requirements. The skills are characterized as the person's ability to utilize, implement and exhibit a group of relevant acknowledgment, expertise, experiences, and behaviors to carry out responsibilities and duties effectively. These can be assessed in line with well-accepted labor-service standards and evaluated against evidence given in the workplace. The competency influences the work obligation and efficiency of the employee at work and is generally split into technological and behavioral. The basic rules should be established on occupation field education, standardize base principles and humanism, ethical and social aspects (Niemi, 2012). The need for a partnership between the competence level of graduates and SKKNI establishes VHS levels of competence.

Competency requirements should be adapted to the needs of the dynamic job market and focused on requirements standards. Arguments supporting that the educational approach is focused on a standard base, regarding with: 1.) Criteria; the aims are to allow students to conduct their competence in a system based on standards and to show professional competence based on the standard; 2.) Rules assess abilities; job ability/standard framework size; 3.) The rules are difficult, typical way to measure the skills and expertise determined/standardized by all students; and 4.) Rules are easy to understand, and the traditional way of educating results are competent or incompetent. VHS is structured to prepare students for entrance into the working world and develop a professional role, developing and becoming a mid-level employee to meet company and business needs (Eichhorst et al., 2013). Driven by VHS education objectives, students must adopt VHS's standard learning competencies based on industry needs to their skills and employment.

The contributors of FGD involve ten persons included of practitioners from internet service providers, 2 (two) persons, academicians of Undiksha 2 (three) persons, Educational and culture Department (Dinas Pendidikan dan Kebudayaan), Vocational Training Department (P4TK), and 4 (four) vocational teachers. The result of FGD is a standardized element of skills should be a distinct issue to provide the relevance and significance of the vocational curriculum to SKKNI linking to the competency industry needs. Curriculum growth problems, skills gained by VHS pupils must be adapted to business needs. The plan follows the view, which argues that vocational schools have unique features (Kissi et al., 2020). Firstly, technical training is proportionally effective as an atmosphere in which students are prepared to mimic the industry surrounding, in which they will practice subsequently. Secondly, a successful vocational school has relevance with the same services as those in the industry. Learners will practice doing the same work as workers in the industry. Learners are educated in the expertise needed in the workplace.

FGD attendees also suggested that the description of the competencies report should be changed to a passport capacity, which comprises all the competencies which VHS learners can learn either at the time of learning in the VHS or in the industry. The skills learned in VHS are distinguished by the technical skills gained in the industry. The level of competence gained in professional school is basic skills (threshold competency), which the professional students acquire, and the core skills gained in the industry when the students perform industrial working experience. The competence level is regarded as the SKKNI competence standard.

\section{Curriculum Development}

The findings of comprehensive interviewing indicate that in addition to the business and industry, academicians in the field of curriculum experts and practitioners from the industry could also contribute to the development of curricula opinions promoting academicians in curriculum elaborations and computer and networks engineering field concentration involved in curriculum creation. The people involved in the process of curriculum development are: 1.) Supervisors, academics experts in vocational training; 2.) In structure, engineering trainers; 3.) Support staff, curriculum/program creators; and 4.) Consultant staff, an expert/technical association committee. Participants should engage in the program, in which the technical components training experts, curriculum experts, and industry experts are effectively and efficiently created (Norton, 2016). 
The expert team has indicated that in designing the curriculum, the needs of the students and social circumstances must be taken into account to address job needs in compliance, which notes that the workforce is the reference point for curricula development when developing a curriculum for vocational education (Flores, 2018). The opinion of Flores suggests that work types connected to job tasking become a guide in the elaboration of the curriculum when designing a training curriculum. Kissi et al. (2020) argues that need to consider other views supporting student needs and social circumstances, indicating that vocational education and training as a formal academic school can expand competence prospects for learners to develop their professional work skills.

\section{Teaching, Learning, and Practicing Development}

The effects of the expert's feedback, which suggests that the module must be a learning resource enhanced by other learning opportunities, claimed that the learning environment must be able to deliver individual education experience and mechanism in the workplace (Norton, 2016). It supports the benefit of vocational education gives an industrial experiencing for the learners and improves the technological skills of learners (Clarke \& Winch, 2007). Technological advances in the vocational learning process will still be streamlined. The origins of learning are thus indeed enriched by technological growth. VHS learning has been developed with modules as a learning medium and strengthened with IT as an additional learning aid.

The learning model must be formed in collaboration, and keeping with the curriculums' requirements noted that vocational training includes: first, a program must convey relation to professional needs. This demonstrates that vocational training programs should apply to the demands of the workplace. Students should be educated in basic skills in the industry. The program for vocational education should include skills related to job competence. For example, knowledge learning from a practitioner (such as adopt information knowledge and skills related to technical assistance like installing and maintaining cable networking) has improved the performance industries by the strong partnership that are more receptive to industry needs (Ariadia et al., 2020). Secondly, knowledge must enhance the learning process, find issues, and solve the problem. This idea illustrates that a method of integrating experience and skills to solve problems of life must be used in learning. This implies that the process of learning must continue to form the foundation of learning development. Thus, the vocational school program must include, for instance, installing cable networking, set up modem routers, and assembling hardware.

Vocational education is based on the following concepts: development. It shows that vocational education has to follow the advancement of technological knowledge and skills/technological competence (Ruhland, 2001). This cannot be prevented as technology progresses with the changing times. Secondly, the labor market ensured the balance between jobs and unemployment needs and among work and trained, skilled workers. That context has a meaning of technical learning context as a supply-side of trained, skilled workers will help balance the demand for skilled workers with employment available. As a result of this claim, a technical institution has to be able to produce skilled, trained workers or professional workers regarding the job or occupation targeted. This statement implies that vocational education and training should collaborate in the workplace or industry to prepare the graduate from vocational schools as professional employees with employability skills such as basic skills, personal qualities, thinking skills, management, technology and ready to enter the world of work (Nugraha et al., 2020). It states that the model has to be created to learn and comply in accordance with the curriculum requirements.

The expert judgment stated that the valuation design must consider the appraisal process, in line with (Clarke \& Winch, 2007) perception that the concept of a relevant curriculum represents an evaluation mechanism to record what has been achieved in the learning process and activity. It also includes the learning process that should be performed and what the evaluation framework needs to be carried out, and how it should be conducted. Evaluation is a larger context term than a basic test, which involves selecting, synthesizing, and analyzing data context.

The basic criteria of competency-based educational design include: 1.) A listed of skills, with a basic standard and aspect of each skill; 2.) The readiness of learners could be the reference for starting the evaluation process; 3 .) The learning is suitable of the planning and designing documents 
module; 4.) The evaluation is regardless with specific standards which have been identified, based on required industry competence needs; 5.) A skill-testing have to be performed on the proven skills in a good manner; 6.) Learners may use subsequent skills in a unit if the competences acquired have been gained; and 7.) Student learning process results are recorded in the book documents by administrative teachers skills (Gervais, 2016). A competence-based assessment is backed by a record of competence that is documented in the skills module in this case. Good integration of the curriculum with the industry needs will represent the business commitment in fact in the Board, allowing the use of the capabilities and experiences of VHS and industry for all parties involved. The VHS industry not only offers a perspective into market needs but also helps industries to affect learning and teaching strategies and policies in VHS in common (Wahyuni et al., 2020).

\section{Industrial Work Practice Development}

Results of expert assessment interviews on the control and evaluation of implementation tasks industrial practice should always take place such that the program can be efficiently assisted by students that stipulate the industrial workplace approach apprenticeship includes arrangements 1.) Its specific educational targets and 2.) The need for apprenticeship assessment for training goals to be achieved. The decisions in the apprenticeship are based on two classifications, namely, (a) The content of an apprenticeship program evaluated to assess the relevance with industry need and (b) Trainers to identify prior knowledge and skills of the participant in the initial curricula in relation to content (Klink \& Streumer, 2006). Industrial experts, as part of the industry's that called an instructor, who was conducting teaching, learning, and practicing must be complemented with an assessment process activity. The assessment of industrial work practices in the competency test model is based on their professional skills achievement, which means that the learners have to perform their job tasks while working in the industry. Learners who can perform the job task suitable for the job procedural have stated themselves professional in this field of vocational expertise. For instance, VHS may obtain experience from industry partners to meet business needs by enabling instructors to create a learning environment to offer students industrial learning experiences (Wahyuni et al., 2020), which can lead to greater organizational success like the employer of graduates.

The workplace competence evaluation research that the evaluator and teacher the study accepted that a competency test based is the complete and comprehensive way (Halliday-Wynes \& Misko, 2013). This approach also allows students to understand basic values and concepts for learning, the relationship between new concepts, and preliminary vocational cognition. In this analysis, the evaluator and the vocational teacher agree that a clear understanding of the meaning of the training and skills test is an important method for students. Strengthened students will conduct industrial competence research.

To develop requirements for job competencies, the Competency-Based Education \& Training (CBAT) divides the entire program into cohesive sections, known as courses or units, and into elements or tasks that can be taught, evaluated, and certified separately. The alignment of skills requirements with the different components of competence (modules, units/elements/takes), performance proof, performance criteria, implementation area, and evaluation guidance are the basis for competency-based training and education CBAT curricula and curricula modular curriculum design. The design of the skills-based curriculum and training system and curricula for a specific job should be much more effective and standard-oriented. This ensures that when training is designed to generate skills that are specifically in line with current expectations, this would be much more successful and have a greater impact than training that is entirely ignorant of the business sector's needs.

\section{Skills Testing Development}

CBA should provide contextual support and professional standards (Haines et al., 2013). The work-based assessment of the learning process is fine. According to the expert judgment, substantive policies and regulations should help the VHS's existence with collaboration between the CBA center and LSP. This view is reinforced by those who said that an autonomous organization focused on industry competence criteria should be one of the principles of vocational training in 
assessing learning outcomes. The competence test in VHS must be carried out to obtain recognition from independent organizations through professional certification authorities, which are recognized through professional certification bodies. According to the guidelines of the BNSP, LSP may be developed in education and training institutions. LSP assessments certified by BNSP are performed for VHS students.

CBA gathers proof of competence from certified assessors. CBA's vocational training has two key aspects: gathering evidence of each student's potential and using that evidence in making decisions about the student's achievement of a national level of competence or a program (HallidayWynes \& Misko, 2013). Competences owned by VHS students in work in an industry and registered as passports of skills can be used as proof of the method of competence testing. LSP shall perform a competency-based assessment in the form of proof of competence. Students who meet the competence criteria are considered to be qualified and LSP certified. Students who are not declared qualified to show competence are not yet eligible. Students seeking to obtain competencies will use their pattern via work/simulation to take an LSP for the competency examination. For example, students who have completed all of their competence packages could qualify as a junior technician proved by a certified professional.

The problem of a credential indicates that a previous competency testing procedure has been completed. The credential is not a diploma that certifies previous studies in a structured framework. It is quite evident and surely based on a well-defined norm of a checked competence. This provides even more clarity for structured certification programs since it enables employers to be aware of the competencies needed by their businesses and training organizations to help their curriculum design processes. The credential is an assurance of consistency of what the worker can do and the qualifications he/she needs to do.

\section{CONCLUSION}

The learning aspect of facilitating the deployment of a competency-based assessment model is 1.) Getting a certificate of competency and being a self-employed evaluator; 2.) A competencybased learning model; 3.) The readiness of students with employability skills who are ready to enter and compete in the industry; 4.) Validated ability guidance for the enrichment of competencies and at the same period proving the accomplishment of competencies; 5.) VHS has CBA centers for assessing student competency; 6.) VHS has become a licensed accredited from LSP as a certification institution. Job training or internship of industry aspects which can help the establishment of the test model the competency-based work are: 1.) Learners must demonstrate mastery skills that can be applied on the real job; 2.) Students must select the industry who has a partnership with VHS related on Memorandum of Understanding (MOU); 3.) Students must follow the training course and determine work/skills, clusters then, accepted by industry; 4.) VHS appoints students for work practice according to industry acceptance; 5 .) Competency examination conducted by actual work practice; and 6.) Hiring expertise industries as external assessors to evaluate competencies student. The process to measure students' employability skills in vocational education is a CBA that integrates the teaching, learning, and practicing technique with the evaluation process activity. Industrial work practices are conducted out while students are utilizing patterns where they work on a real job..

\section{REFERENCES}

Albanese, M. A., Mejicano, G., Anderson, W. M., \& Gruppen, L. (2010). Building a competencybased curriculum: The agony and the ecstasy. Advances in Health Sciences Education, 15(3), 439-454. https://doi.org/10.1007/s10459-008-9118-2

Alonzo, A. C. (2018). An argument for formative assessment with science learning progressions. Applied Measurement in Education, 31(2), 104-112. https://doi.org/10.1080/08957347.2017.1408630 
Ariadia, G., Surachmana, S., Sumiatia, S., \& Rohmana, F. (2020). The effect of strategic external integration on financial performance with mediating role of manu- facturing flexibility: Evidence from bottled drinking industry in Indonesia. Management Science Letters, 10(15), 3495-3506. https://doi.org/10.5267/j.msl.2020.6.045

Bamalli, H. S. (2014). Competencies and strategies for the teaching of 21 st century learners in vocational home economics education. International Letters of Social and Humanistic Sciences, 19(8), 50-55. https://doi.org/10.18052/www.scipress.com/ILSHS.19.50

Clarke, L., \& Winch, C. (2007). Vocational education: International approaches, developments and systems (1st ed.). Routledge. https://doi.org/10.4324/9780203815298

Craddock, D., O'Halloran, C., McPherson, K., Hean, S., \& Hammick, M. (2013). A top-down approach impedes the use of theory? Interprofessional educational leaders' approaches to curriculum development and the use of learning theory. Journal of Interprofessional Care, 27(1), 65-72. https://doi.org/10.3109/13561820.2012.736888

Eichhorst, W., Rodríguez-Planas, N., Schmidl, R., \& Zimmermann, K. F. (2013). A roadmap to vocational education and training systems around the world. IZA Discussion Paper No. 7110. https://ssrn.com/abstract=2199793

Fletcher, S. (2000). Competence-based assessment techniques (2nd ed.). Kogan Page.

Flores, M. A. (2018). Teacher resilience in adverse contexts: Issues of professionalism and professional identity (M. Wosnitza, F. Peixoto, S. Beltman, \& C. F. Mansfield (eds.); pp. 167-184). Springer International Publishing. https://doi.org/10.1007/978-3-319-766904_10

Gervais, J. (2016). The operational definition of competency-based education. The Journal of Competency-Based Education, 1(2), 98-106. https://doi.org/https://doi.org/10.1002/cbe2.1011

Grosch, M. (2017). Developing a competency standard for TVET teacher education in Asean Countries. Jurnal Pendidikan Teknologi Dan Kejuruan, 23(3), 279-287. https://doi.org/doi.org/10.21831/jptk.v23i3.13418

Haines, C., Dennick, R., \& da Silva, J. A. P. (2013). Developing a professional approach to workbased assessments in rheumatology. Best Practice \& Research Clinical Rheumatology, 27(2), 123-136. https://doi.org/https://doi.org/10.1016/j.berh.2013.02.006

Halliday-Wynes, S., \& Misko, J. (2013). Assessment issues in VET: minimising the level of risk. NCVER.

Hasan, A., \& Pardjono, P. (2019). The correlation of higher order thinking skills and work readiness of vocational high school students. Jurnal Pendidikan Teknologi Dan Kejuruan, 25(1), 5261. https://doi.org/10.21831/jptk.v25i1.19118

Kissi, E., Ahadzie, D. K., Debrah, C., \& Adjei-Kumi, T. (2020). Underlying strategies for improving entrepreneurial skills development of technical and vocational students in developing countries: using Ghana as a case study. Education + Training, 62(5), 599-614. https://doi.org/10.1108/ET-11-2019-0264

Klink, M. R. Van Der, \& Streumer, J. N. (2006). Explaining the (In)effectiveness of on-the-job training. International Journal of Human Resources Development and Management, 6(1), 114-130. https://doi.org/10.1504/IJHRDM.2006.009752

Niemi, H. (2012). The societal factors contributing to education and schooling in Finland BT miracle of education: The principles and practices of teaching and learning in Finnish Schools (H. Niemi, A. Toom, \& A. Kallioniemi (eds.); pp. 19-38). SensePublishers. https://doi.org/10.1007/978-94-6091-811-7_2

Norton, M. S. (2016). Guiding curriculum development. Rowman \& Littlefield. 
Nugraha, H. D., Kosasih, D. P., Kasda, K., Djohar, A., \& Komaro, M. (2020). Model of essential employability skills framework for machine operator. Jurnal Pendidikan Vokasi, 10(2), 188202. https://doi.org/10.21831/jpv.v10i2.31869

Patton, M. Q. (2014). Qualitative research \& evaluation methods (4th ed.). SAGE Publications, Inc.

Presiden Republik Indonesia. (2003). Undang-Undang Republik Indonesia Nomor 20 Tahun 2003 tentang Sistem Pendidikan Nasional.

Ruhland, S. (2001). Factors that influence the turnover and retention of Minnesota's Technical College Teachers. Journal of Vocational Education Research, 26(1), 56-76. https://doi.org/10.5328/JVER26.1.56

Sandelowski, M. (2000). Whatever happened to qualitative description? Research in Nursing \& Health, 23(4), 334-340. $\quad$ https://doi.org/https://doi.org/10.1002/1098240X(200008)23:4<334::AID-NUR9>3.0.CO;2-G

Wahyuni, D. S., Sudira, P., Agustini, K., \& Ariadi, G. (2020). The effect of external learning on vocational high school performance with mediating role of in- structional agility and product innovation efficacy in Indonesia. Management Science Letters, 10(16), 3931-3940. https://doi.org/10.5267/j.msl.2020.7.017 